\title{
Definition, classification and mechanism of action of endocrine disrupting chemicals
}

\author{
Wolfgang Wuttke, Hubertus Jarry, Dana Seidlova-Wuttke
}

Department of Endocrinology, University Medical Center Goettingen, Georg-August-University, Germany

Hormones are peptides/proteins, lipids or aminoacid derivatives which after their secretion act on receptors to cause reactions within the respective receptive cells. Each cell of the body is in one way or another regulated by hormones. Hence, hormones exert innumerable effects on the organism of animals and humans.

These multiple effects can be adversely deregulated by Endocrine Disrupting chemicals, (EDs), which are taken up through food or drinks or through the air. Occasionally, they are also absorbed transdermally. This topic has been dealt with in an Endocrine Society scientific statement. ${ }^{1}$ EDs are mainly unintentionally taken but there are also examples of intentional intake of substances possessing putative ED properties.

Basically, hormones vitally modify three biological processes: they are essential for reproduction, for optimal survival and for normal biological performance. Hence, they are essential for the maintenance

Key words: Bisphenol-A, Endocrine disruptors, Fungicides, Herbicides, Isoflavones, Pesticides, Phtalates

Address for correspondence:

Prof. Dr. Wolfgang Wuttke, Department of Endocrinology, University Medical Center Goettingen, Georg-AugustUniversity, Robert-Koch-Strasse 40, D-37099 Goettingen/ Germany, Tel.: +49-551-396714, Fax: +49-551-396518, E-mail: ufkendo@med.uni-goettingen.de

Received 10-11-09, Revised 12-12-09, Accepted 28-12-09 of species and for coping with daily environmental influences

Most EDs may interact with the effects of lipid (steroid) or aminoacid derived (thyroid) hormones, while a few interact with peptide/protein hormone synthesis or signalling. However, effects of EDs through steroid receptors on peptide/protein hormones are common. Some examples of action of EDs are given in Tables 1 and 2.

Other less well explored mechanisms of action of EDs are direct effects on genes. Estrogens and EDs with estrogenic action were, for example, suggested as causing DNA damage, thereby promoting malignant differentiation of affected cells. ${ }^{2}$ A troubling new aspect is their epigenetic impact; the amount of methylation of genes occurring early in life may have profound effects years later ${ }^{3,4}$ and may even be transgenerationally inherited. ${ }^{5}$

Most EDs interfere with reproduction. They act as either agonists or antagonists of the steroidal sex hormones, estrogens or androgens. A number of EDs interfere with the daily necessity of coping with internal or environmental stress and other adverse events. Fortunately, very few EDs exert a life-threatening impact through interference with hormone systems necessary to maintain basic life-sustaining mechanisms. Nevertheless, the effects of some EDs may be life-threatening because they may interfere with the normal functions of organs or cause malignancies of these organs.

There follows a discussion concerning the basic 
Table 1. Mechanisms of action of EDs: binding to receptors

\begin{tabular}{|c|c|c|c|c|}
\hline Substances & Mechanisms & Major effect & Biological effects & References \\
\hline \multicolumn{5}{|l|}{ Agonists } \\
\hline Bisphenol-A; & \multirow[t]{5}{*}{ Activation via ERE } & \multirow[t]{5}{*}{ Estrogenic } & \multirow{5}{*}{$\begin{array}{l}\text { Adverse effects on } \\
\text { reproduction; uterus, } \\
\text { mammary gland }\end{array}$} & $(39)$ \\
\hline Phtalates & & & & $(40)$ \\
\hline Polyphenols including isoflavones & & & & $(41) ;(22,42)$ \\
\hline and genistein & & & & $(18) ;(4,19)$ \\
\hline $\begin{array}{l}\text { Some UV-screens (benzophenone } 2 \text {; } \\
\text { cinnamate; camphor devivatives }\end{array}$ & & & & \\
\hline \multicolumn{5}{|l|}{ Antagonists } \\
\hline $\begin{array}{l}\text { Pesticides, fungicides, herbicides } \\
\text { (linurone, procymidone, vinclocolin) } \\
\text { dioxin }\end{array}$ & $\begin{array}{l}\text { Various mechanism } \\
\text { often inhibition } \\
\text { of ARE mediation }\end{array}$ & Antiandrogenic & $\begin{array}{l}\text { Adverse effects on } \\
\text { reproduction }\end{array}$ & (1) \\
\hline
\end{tabular}

EDs: Endocrine disruptors, ERE: Estrogen Response Elements, ARE: Androgene Response Elements

Table 2. Mechanisms of action of endocrine disrupting chemicals; effects on enzymes or transport proteins

\begin{tabular}{|c|c|c|c|}
\hline Substances & Mechanism & Affected hormone(s) Biological effect & References \\
\hline $\begin{array}{l}\text { Fungicides } \\
\text { (azoles) }\end{array}$ & $\begin{array}{c}\text { Synthesis inhibitors: Inhibition affected } \\
\text { step of synthesis (sterol demethylase } \\
\text { and chromatase) }\end{array}$ & $\begin{array}{l}\text { All steroids; } \\
\text { inhibition of adrenal steroids } \\
\text { is particularly important; } \\
\text { life-threatening reduction of adrenal corticoids }\end{array}$ & $(43) ;(44)$ \\
\hline Isoflavones & Inhibition of thyroid peroxidase & Thyroxin synthesis (hypothyroidism) & $(45)$ \\
\hline \multirow[t]{2}{*}{$\begin{array}{l}\text { Polyphenols } \\
\text { (isoflavones, genistein) }\end{array}$} & $\begin{array}{c}\text { Sulfatase increased } \\
\text { decreased sulfo-transferase }\end{array}$ & Free estrogen increased & $(46) ;(47)$ \\
\hline & Effects on proteins transport & & \\
\hline $\begin{array}{l}\text { Isoflavones, } \\
\text { polychlorinated diphenols }\end{array}$ & $\begin{array}{c}\text { Transthyretin (the transport protein } \\
\text { of thyroid hormones) }\end{array}$ & Altered amounts of free thyroid hormones & $(48) ;(41)$ \\
\hline
\end{tabular}

mechanism of EDs actions, some of which are detailed in the Tables.

\section{REPRODUCTION}

The effects of EDs on reproduction are amply documented in both marine and terrestrial species, and in humans. Maintenance of species is dependent on an integrated interplay of the entire endocrine system. Reproduction ceases when life-supporting hormonal systems are disturbed, but "performance"supporting hormones are also needed to maintain normal reproduction.

Of major importance for reproduction is normal functioning of the reproductive system, i.e. the hypothalamo-pituitary-gonadal axis, as well as the proper functioning of other organs regulated by gonadal steroids, such as the uterus and to some degree the mammary gland. Most EDs that disrupt reproduction interfere with steroidal signalling, i.e. with the proper action of estrogens or androgens. Some EDs either inhibit synthesis or interfere with the metabolism of sex steroids. Most EDS with adverse effects on reproduction bind either to the estrogen receptors (ERs) or to the androgen receptor (AR) and, by doing so, may either stimulate or inhibit the transcriptional or post-transcriptional mechanisms; moreover, steroid receptors located in the membrane, affecting either ion channels or $2^{\text {nd }}$ messengers, may mediate ED effects. By means of these mechanisms, they may interfere with fundamental sex steroid effects on the brain, the pituitary gland, the gonads and the 
accessory sex organs, such as the uterus and mammary gland in females and the prostate and seminal vesicles in males.

The classical endocrine disruptors are the dioxins, which bind to the arylhydrocarbon receptor (AhR; formerly also called dioxin receptor). After dimerizing with the arylhydrocarbon receptor translocator (ARNT), the resulting transcriptional activity increases the activity of the cytocrome P $4501 \mathrm{~A} 1$ gene resulting in higher production of CYP 1A1, an enzyme involved in detoxification of a number of environmental substances. ${ }^{6,7}$

Of major concern is the fact that endocrine disruptors interfering with reproduction may have profound effects on sexual differentiation. There have been many examples demonstrating disturbed sexual development of animals in areas polluted with EDs. ${ }^{8-10}$ The most dominant endocrine disruptors interfering with reproduction and sexual differentiation have either estrogenic or antiestrogenic effects. There is good evidence that the consumption of oral contraceptives containing ethinylestradiol contaminates waste water. This strong estrogen is unmetabolized excreted through the urine and its clearance through bacteria in waste water is incomplete. Therefore, ethinylestradiol is present, in biologically active concentrations in waste water drainages into rivers and this has profound effects on aquatic life in these areas. ${ }^{11-13}$

Pollution of surface water with pesticides, fungicides or herbicides is also of great concern since most of them have relatively strong antiandrogenic effects. ${ }^{1}$ Through incorporation into aquatic life forms, these substances may also enter the human and animal food chain. In addition, the antiandrogenic substances used in pesti-, fungi- or herbicides can directly contaminate our daily food.

Both estrogens and antiandrogenic compounds in surface waters have profound effects on aquatic life. Feminisation or demasculinisation of molluscs, arthropods and fish have been reported in polluted lakes or rivers (Lake Apopka). ${ }^{14,15}$

Lately, the endocrine disrupting effects of bisphenol-A has raised great concern. In the United States discussions are taking place as to whether bisphenol-A should be used as a plasticizer. In animal experiments, minute amounts were effective in causing adverse effects, whereas these effects were not exerted by larger amounts of this plasticizer. It remains unclear why minute amounts of this compound are more effective in eliciting endocrine disrupting effects than higher doses. ${ }^{4,16-19}$ It has been claimed that bisphenol-A acts on estrogen receptors.

Concern has also recently been expressed regarding the putative endocrine disrupting effects of some substances protecting the skin against ultraviolet radiation. ${ }^{20,21}$ Some of these UV screens have proved to exert estrogenic effects: benzophenone 2, in particular, was almost as active as the native estrogen estradiol$17 \beta$, primarily by addressing estrogen receptor alpha signalling. ${ }^{22,23}$ Benzophenone-2 has therefore been banned as a UV screen for human use, especially since it was also shown to penetrate the skin and circulate in serum. Additionally, other UV screens such as 4methylene-benzolidin-camphor (4-MBC) and some cinnamates have mild estrogenic effects and their mechanism of action involves activation of estrogen receptors and recruitment of cofactors. ${ }^{24}$

As already mentioned, most endocrine disruptors are present as ingestible or inhalable chemicals which are often unwittingly taken up. There are, however, endocrine disruptors which are intentionally taken up like phytoestrogens which the Environmental Protection Agency (EPA) considers to be potential endocrine disruptors.

According to a list of endocrine disruptors published by the EPA, isoflavones, present in a variety of soy-derived foodstuffs, have relatively strong estrogenic effects. Their presence in baby food is of particular concern. Moreover, a large number of food additives is present on the market for the treatment of climacteric and postmenopausal complaints or diseases. This results in many women, suffering from climacteric dysfunctions, ingesting high amounts of highly purified isoflavones. It is currently being debated whether the estrogenic properties of these high amounts of isoflavones may have adverse effects on the mammary gland or the uterus.

These isoflavones are intentionally or unintentionally administered, as, for example, when parents feed their babies soy-containing baby food. Soy is the major protein source in many baby food formulas. It contains 
estrogenic isoflavones which are absorbed through the infant's gastro-intestinal tract and, in fact, measurement of isoflavones and their metabolites in the urine of babies has revealed that large quantities are present in infants' urine. In table 3, the average intake of isoflavones by Japanese women and US American vegetarians are compared with the isoflavone uptake through a soy-containing baby food formula. Serum concentrations of isoflavones in Japanese women were in the range of $10^{-6} \mathrm{M}$ to $10^{-8} \mathrm{M},{ }^{25}$ those in soy formula fed babies amounted to $10^{-5} \mathrm{M}$, and in the urine were even higher. ${ }^{26}$ Hence, amounts of isoflavones in some baby formulas exceed those taken up by the average Japanese (on the basis of per $\mathrm{kg} \mathrm{BW}$ ) by a factor of $>10$ (Table 3). High amounts of isoflavones given to newborn rats resulted in disturbance of estrous cyclicity at a very early stage of life. ${ }^{27}$

Experimental data from cell cultures and whole animal studies showed that such concentrations had strong estrogenic effects. ${ }^{28}$ Furthermore, they may imprint many organs, including the brain, to develop diseases much later in life. Severe disturbances of high doses of isoflavones on reproduction were demonstrated in mice and rats. ${ }^{29,30}$ Another distressing observation is that some isoflavones are inhibitors of topoisomerase II. When such inhibition occurs during fetal life, an increased risk for later development of leukemia is anticipated. ${ }^{31}$ Various adverse effects of prenatal genistein (an isoflavone) treatment on the reproductive tract ${ }^{32}$ have also been reported. Such effects have not been proven and seem not to occur in the Japanese population. Isoflavones are also propagated as an alternative for hormone replacement therapy in women suffering from climacteric symptoms or in women at risk for the development of osteoporosis or arteriosclerosis. Companies producing soy/red clover/isoflavone-containing preparations for ageing women claim that their products have solely beneficial estrogenic effects without the putative adverse effects of estrogens in the mammary gland. In fact, it is often suggested that isoflavones may prevent mammary cancer. Consequently, the claim is made that the isoflavones are ideal selective estrogen receptor modulators. In recent reviews, ${ }^{33,34}$ however, the efficacy of these products to alleviate climacteric symptoms has been questioned. Since many patients believe "little helps little, more helps more", they often take more than the recommended $50 \mathrm{mg}$ quantity per day. In a large placebo-controlled study, the uptake of $150 \mathrm{mg}$ of isoflavones per day had clear uterotrophic effects, since $3.37 \%$ of the postmenopausal women developed endometrial hyperplasia, whereas this was not observed in the placebo treated controls. ${ }^{35}$

The rationale of such claims for isoflavones is based on what is known as the "Japanese phenomenon": Japanese women when living in Japan have significantly fewer mammary cancers than Caucasian American or European women, whereas when they migrate to the United States, the first daughter generation develop mammary cancer as often as do Caucasian women. This indicates that it is not genetic but rather environmental factors that are responsible for the differences in the development of mammary cancer. It soon turned out that the isoflavones present in soy food, which is the dominant protein source in Japanese nutrition, might exert the anticancer effects. After migrating to the United States, much more meat is consumed and, therefore, the isoflavone intake is minimized. On that basis, companies producing isoflavone-containing soy or red clover prepara-

Table 3. Phytoestrogen intake via diets by infants and adults

\begin{tabular}{lcc}
\hline & $\begin{array}{c}\text { Average isoflavone intake } \\
\text { mg/per day }\end{array}$ & $\begin{array}{c}\text { Isoflavones mg/kg body } \\
\text { weight/day }\end{array}$ \\
\hline Japan (1996 survey) & 10 & 0.17 \\
Japan (1996 survey) & 28 & 0.47 \\
In American women, preferentially eating vegetarian diet & 45 & 0.75 \\
FDA recommended amount for adults & 25 & 0.42 \\
Infants receiving soy formula & 38 & 6.25 \\
& & *Assumed $60 \mathrm{~kg}$ for adults, \\
\end{tabular}


tions claim that their product may prevent mammary cancers when given to climacteric/postmenopausal women. This concept has recently been challenged by the observation that carcinogen-induced mammary tumours in rats can be significantly prevented only by pre- and peripubertal administration of isoflavones, and particularly of genistein. ${ }^{36}$ This concept was confirmed by the observation that Japanese girls migrating to the United States prior to puberty have significantly higher risks for developing mammary cancers than Japanese migrating after puberty. ${ }^{37,38}$ Thus, it appears that the mammary cancer preventing effects of isoflavones are exerted at a crucial developmental period, namely the time of puberty, i.e. when mammary glands develop. This prompts the urgent question as to whether isoflavones, when given to "isoflavone inexperienced" women at the time of menopause, may have harmful effects.

Taken collectively, the effects of dietary isoflavones in newborns and climacteric/postmenopausal women are of great concern and need to be further investigated.

In a number of experiments, and particularly in experiments using estrogen receptor expressing cancer cells, the effects of minute amounts of substances known to have estrogenic effects potentiate each other, being not only additive but supra-additive. Therefore, a multitude of endocrine disrupting effects may be anticipated when combinations of endocrine disruptors are polluting our environment and are incorporated by plants or animals that are part of our food chain. Clearly, more work is necessary for a better understanding of the effects of endocrine disruptors in humans.

\section{REFERENCES}

1. Diamanti-Kandarakis E, Bourguignon JP, Giudice LC, et al, 2009 Endocrine-disrupting chemicals: an Endocrine Society scientific statement. Endocr Rev 30: 293-342.

2. Bolton JL, Thatcher GR, 2008 Potential mechanisms of estrogen quinone carcinogenesis. Chem Res Toxicol 21: 93-101.

3. Jirtle RL, Skinner MK, 2007 Environmental epigenomics and disease susceptibility. Nat Rev Genet 8: 253-262.

4. Moral R, Wang R, Russo IH, Lamartiniere CA, Pereira J, Russo J, 2008 Effect of prenatal exposure to the endocrine disruptor bisphenol A on mammary gland morphology and gene expression signature. J Endocrinol
196: 101-112.

5. Anway MD, Skinner MK, 2008 Epigenetic programming of the germ line: effects of endocrine disruptors on the development of transgenerational disease. Reprod Biomed Online 16: 23-25.

6. Beischlag TV, Luis Morales J, Hollingshead BD, Perdew GH, 2008 The aryl hydrocarbon receptor complex and the control of gene expression. Crit Rev Eukaryot Gene Expr 18: 207-250.

7. Swedenborg E, Pongratz I, 2009 AhR and ARNT modulate ER signaling. Toxicology [Epub ahead of print]

8. Dickerson SM, Gore AC, 2007 Estrogenic environmental endocrine-disrupting chemical effects on reproductive neuroendocrine function and dysfunction across the life cycle. Rev Endocr Metab Disord 8: 143-159.

9. Panzica GC, Mura E, Miceli D, Martini MA, Gotti S, Viglietti-Panzica C, 2009 Effects of xenoestrogens on the differentiation of behaviorally relevant neural circuits in higher vertebrates. Ann N Y Acad Sci 1163: 271-278.

10. Kloas W, Urbatzka R, Opitz R, et al, 2009 Endocrine disruption in aquatic vertebrates. Ann N Y Acad Sci 1163: 187-200.

11. Bjorkblom C, Hogfors E, Salste L, et al, 2009 Estrogenic and androgenic effects of municipal wastewater effluent on reproductive endpoint biomarkers in three-spined stickleback (Gasterosteus aculeatus). Environ Toxicol Chem 28: 1063-1071.

12. Johnson A, Tanaka H, Okayasu Y, Suzuki Y, 2007 Estrogen content and relative performance of Japanese and British sewage treatment plants and their potential impact on endocrine disruption. Environ Sci 14: 319329.

13. Lee YM, Oleszkiewicz JA, Cicek N, Londry K, 2004 Endocrine disrupting compounds (EDC) in municipal wastewater treatment: a need for mass balance. Environ Technol 25: 635-645.

14. Guillette LJ Jr, Edwards TM, Moore BC, 2007 Alligators, contaminants and steroid hormones. Environ Sci 14: 331-347.

15. Crain DA, Janssen SJ, Edwards TM, et al, 2008 Female reproductive disorders: the roles of endocrine-disrupting compounds and developmental timing. Fertil Steril 90: 911-940.

16. vom Saal FS, Hughes C, 2005 An extensive new literature concerning low-dose effects of bisphenol A shows the need for a new risk assessment. Environ Health Perspect 113: 926-933.

17. Sekizawa J, 2008 Low-dose effects of bisphenol A: a serious threat to human health? J Toxicol Sci 33: 389-403.

18. Jenkins S, Raghuraman N, Eltoum I, Carpenter M, Russo J, Lamartiniere CA, 2009 Oral exposure to bisphenol a increases dimethylbenzanthracene-induced mammary cancer in rats. Environ Health Perspect 117: 910-915.

19. Moral R, Wang R, Russo IH, Mailo DA, Lamartiniere CA, Russo J, 2007 The plasticizer butyl benzyl phthalate induces genomic changes in rat mammary gland 
after neonatal/prepubertal exposure. BMC Genomics 8: 453.

20. Schlumpf M, Jarry H, Wuttke W, Ma R, Lichtensteiger W, 2004 Estrogenic activity and estrogen receptor beta binding of the UV filter 3-benzylidene camphor. Comparison with 4-methylbenzylidene camphor. Toxicology 199: 109-120.

21. Schlumpf M, Schmid P, Durrer S, et al, 2004 Endocrine activity and developmental toxicity of cosmetic UV filters-an update. Toxicology 205: 113-122.

22. Schlecht C, Klammer H, Wuttke W, Jarry H, 2006 A dose-response study on the estrogenic activity of benzophenone- 2 on various endpoints in the serum, pituitary and uterus of female rats. Arch Toxicol 80: 656-661.

23. Schlecht C, Klammer H, Frauendorf H, Wuttke W, Jarry H, 2008 Pharmacokinetics and metabolism of benzophenone 2 in the rat. Toxicology 245: 11-17.

24. Klammer H, Schlecht C, Wuttke W, et al, 2007 Effects of a 5-day treatment with the UV-filter octyl-methoxycinnamate (OMC) on the function of the hypothalamo-pituitary-thyroid function in rats. Toxicology 238: 192-199.

25. Cassidy A, Albertazzi P, Lise Nielsen I, et al, 2006 Critical review of health effects of soyabean phyto-oestrogens in post-menopausal women. Proc Nutr Soc 65: 76-92.

26. Cao Y, Calafat AM, Doerge DR, et al, 2009 Isoflavones in urine, saliva, and blood of infants: data from a pilot study on the estrogenic activity of soy formula. J Expo Sci Environ Epidemiol 19: 223-234.

27. Delclos KB, Weis CC, Bucci TJ, et al, 2009 Overlapping but distinct effects of genistein and ethinyl estradiol $(\mathrm{EE}(2))$ in female Sprague-Dawley rats in multigenerational reproductive and chronic toxicity studies. Reprod Toxicol 27: 117-132.

28. Mueller SO, Simon S, Chae K, Metzler M, Korach KS, 2004 Phytoestrogens and their human metabolites show distinct agonistic and antagonistic properties on estrogen receptor alpha (ERalpha) and ERbeta in human cells. Toxicol Sci 80: 14-25.

29. Jefferson WN, Padilla-Banks E, Newbold RR, 2005 Adverse effects on female development and reproduction in CD-1 mice following neonatal exposure to the phytoestrogen genistein at environmentally relevant doses. Biol Reprod 73: 798-806.

30. Kouki T, Kishitake M, Okamoto M, Oosuka I, Takebe M, Yamanouchi K, 2003 Effects of neonatal treatment with phytoestrogens, genistein and daidzein, on sex difference in female rat brain function: estrous cycle and lordosis. Horm Behav 44: 140-145.

31. Barjesteh van Waalwijk van Doorn-Khosrovani S, Janssen J, Maas LM, Godschalk RW, Nijhuis JG, van Schooten FJ, 2007 Dietary flavonoids induce MLL translocations in primary human CD34+ cells. Carcinogenesis 28: 1703-1709.

32. Jefferson WN, Padilla-Banks E, Goulding EH, Lao SP, Newbold RR, Williams CJ, 2009 Neonatal exposure to genistein disrupts ability of female mouse reproductive tract to support preimplantation embryo development and implantation. Biol Reprod 80: 425-431.

33. Lethaby AE, Brown J, Marjoribanks J, Kronenberg F, Roberts H, Eden J, 2007 Phytoestrogens for vasomotor menopausal symptoms. Cochrane Database Syst Rev: CD001395.

34. Wuttke W, Jarry H, Seidlova-Wuttke D, 2007 Isoflavones-safe food additives or dangerous drugs? Ageing Res Rev 6: 150-188.

35. Unfer V, Casini ML, Costabile L, Mignosa M, Gerli S, Di Renzo GC, 2004 Endometrial effects of long-term treatment with phytoestrogens: a randomized, doubleblind, placebo-controlled study. Fertil Steril 82: 145-148, quiz 265.

36. Lamartiniere CA, 2002 Timing of exposure and mammary cancer risk. J Mammary Gland Biol Neoplasia 7: 67-76.

37. Ziegler RG, Hoover RN, Pike MC, et al, 1993 Migration patterns and breast cancer risk in Asian-American women. J Natl Cancer Inst 85: 1819-1827.

38. Shu XO, Jin F, Dai Q, et al, 2001 Soyfood intake during adolescence and subsequent risk of breast cancer among Chinese women. Cancer Epidemiol Biomarkers Prev 10: 483-488.

39. Adewale HB, Jefferson WN, Newbold RR, Patisaul HB, 2009 Neonatal bisphenol-a exposure alters rat reproductive development and ovarian morphology without impairing activation of gonadotropin-releasing hormone neurons. Biol Reprod 81: 690-699.

40. Newbold RR, Jefferson WN, Padilla-Banks E, 2009 Prenatal exposure to bisphenol a at environmentally relevant doses adversely affects the murine female reproductive tract later in life. Environ Health Perspect 117: 879-885.

41. Schmutzler C, Bacinski A, Gotthardt I, et al, 2007 The ultraviolet filter benzophenone 2 interferes with the thyroid hormone axis in rats and is a potent in vitro inhibitor of human recombinant thyroid peroxidase. Endocrinology 148: 2835-2844.

42. Schlecht C, Klammer H, Jarry H, Wuttke W, 2004 Effects of estradiol, benzophenone- 2 and benzophenone- 3 on the expression pattern of the estrogen receptors (ER) alpha and beta, the estrogen receptor-related receptor 1 (ERR1) and the aryl hydrocarbon receptor (AhR) in adult ovariectomized rats. Toxicology 205: 123-130.

43. Vanden Bossche H, Marichal P, Gorrens J, Coene MC, 1990 Biochemical basis for the activity and selectivity of oral antifungal drugs. Br J Clin Pract Suppl 71: 41-46.

44. Moreira VM, Salvador JA, Vasaitis TS, Njar VC, 2008 CYP17 inhibitors for prostate cancer treatment-an update. Curr Med Chem 15: 868-899.

45. Doerge DR, Chang HC, 2002 Inactivation of thyroid peroxidase by soy isoflavones, in vitro and in vivo. $\mathbf{J}$ Chromatogr B Analyt Technol Biomed Life Sci 777: 269-279.

46. Harris RM, Wood DM, Bottomley L, et al, 2004 Phy- 
toestrogens are potent inhibitors of estrogen sulfation: implications for breast cancer risk and treatment. J Clin Endocrinol Metab 89: 1779-1787.

47. Reinen J, Vriese E, Glatt H, Vermeulen NP, 2006 Development and validation of a fluorescence HPLCbased screening assay for inhibition of human estrogen sulfotransferase. Anal Biochem 357: 85-92.

48. Radovic B, Mentrup B, Kohrle J, 2006 Genistein and other soya isoflavones are potent ligands for transthyretin in serum and cerebrospinal fluid. Br J Nutr 95: 1171-1176. 